\title{
Generasi Z Siap Jadi Pemimpin: Edukasi Leadership dan Decision Making Kesehatan Remaja di Banyuwangi
}

\section{Generation Z Ready to be A Leader: Leadership and Decision-Making Adolescent Health Education in Banyuwangi District}

\author{
Syifa'ul Lailiyah*1, Susy Katikana Sebayang ${ }^{2}$, Desak Made Sintha Kurnia Dewi ${ }^{2}$, Erni Astutik ${ }^{3}$, Septa Indra \\ Puspikawati ${ }^{4}$, Diansanto Prayoga ${ }^{1}$, Jayanti Dian Eka Sari ${ }^{5}$, Rizki Putri Hariyani ${ }^{6}$, Erlin Qur'atul Aini ${ }^{6}$
}

\begin{abstract}
ABSTRAK
Latar Belakang: Kabupaten Banyuwangi merupakan kabupaten dengan jumlah kasus pernikahan dini tertinggi di Jawa Timur tahun 2019 sebanyak 352. Pernikahan dini memberikan dampak yang serius terhadap kesehatan reproduksi dan mental perempuan. Remaja perempuan yang menikah usia muda berpotensi mengalamai kehamilan berisiko tinggi dan bahkan kematian. Pernikahan dini juga membatasi perkembangan kedewasaan fisik, emosional, dan pribadi yang diperlukan untuk keberhasilan dan keamanan transisi menuju dewasa. Secara umum, pernikahan dini memiliki dampak yang besar bagi kesehatan masyarakat. Oleh karena itu, remaja penting dibekali pengetahuan dan kemampuan untuk menangkal pengaruh negatif, informasi kesehatan yang tidak benar (hoax) dan mencegah terjadinya perilaku yang berisiko terhadap kesehatan.

Tujuan: Pengabdian kepada masyarakat Siap Jadi Pemimpin bertujuan untuk meningkatkan pengetahuan tentang leadership dan decision making dalam kesehatan remaja pada generasi $\mathrm{Z}$ di Banyuwangi.

Metode: Metode kegiatan pengabdian kepada masyarakat Siap Jadi Pemimpin adalah edukasi secara daring. Edukasi secara daring menggunakan aplikasi zoom meeting. Media edukasi yang digunakan adalah video dan poster. Edukasi dilaksanakan sebanyak 3 sesi. Sasaran kegiatan ini adalah siswa kelas VII sampai XI di Kecamatan Licin dan Kecamatan Banyuwangi Kabupaten Banyuwangi. Kegiatan ini dilaksanakan pada bulan Oktober 2020. Evaluasi pengabdian kepada masyarakat meliputi kehadiran peserta, pelaksanaan kegiatan, dan pengetahuan peserta.

Hasil: Jumlah peserta yang hadir adalah 120 orang $(27,21 \%)$. Evaluasi pelaksanaan kegiatan termasuk dalam kategori sangat baik. Peningkatan pengetahuan peserta kegiatan sebesar 3,63\%. Jumlah peserta yang pengetahuannya meningkat sebesar 36,36\% dengan peningkatan pengetahuan sebesar 15,63\%.

Kesimpulan: Kegiatan pengabdian kepada masyarakat ini dapat meningkatkan pengetahuan peserta kegiatan tentang leadership dan decision making dalam kesehatan remaja pada generasi $\mathrm{Z}$ di Kabupaten Banyuwangi.
\end{abstract}

Kata Kunci: Edukasi, Generasi Z, leadership, decision making

\section{ABSTRACT}

Background: Banyuwangi was the district with the highest early marriage number of cases in East Java in 2019, with an amount were 352 cases. Early marriage has a serious impact on women's reproductive and mental health. Adolescent girls who are married at a young age have the potential to experience high-risk pregnancies and even death. Early marriage also limited the development of physical, emotional, and personal maturity necessary for a successful and secure transition to adulthood. In general, early marriage has a big impact on public health. Therefore, it was important for adolescents to be equipped with the knowledge and abilities toward negative influences, false health information (hoaxes), and prevented behaviors that posed a health risk.

Objectives: The purpose of Ready to be a Leader Community Services was to increase the knowledge about leadership and decision-making adolescent health in Banyuwangi District.

Methods: Leadership and decision-making in adolescent health education for generation $Z$ used the zoom meeting application. The media education was video and poster. The method of Ready to be a Leader Community Services was online education. The education was carried out in 3 sessions. The target of this activity was students in grades VII to XI in Licin Sub-district and Banyuwangi Sub-district, Banyuwangi District. This activity was held in October 2020. Evaluation of community service included participant attendance, activity implementation, and participant knowledge. 
Results: The number of participants who attended was 120 people $(27.21 \%)$. The result evaluation of the implementation of the activities was a very good category. The increased knowledge of participants was $3.63 \%$. The number of participants whose knowledge increased was 36.36\% with an increased knowledge was $15.63 \%$. Conclusions: This community services activity increased the knowledge of participants about leadership and decision-making of generation $Z$ adolescent's health in Banyuwangi District.

Keywords: Education, Z Generation, leadership, decision making

*Koresponden :

syifaul.lailiyah@fkm.unair.ac.id

Syifa'ul Lailiyah

${ }^{* 1}$ Departemen Administrasi dan Kebijakan Kesehatan, Fakultas Kesehatan Masyarakat, PSDKU Universitas Airlangga, Banyuwangi, Jawa Timur

${ }^{2}$ Departemen Biostatistika dan Kependudukan, Fakultas Kesehatan Masyarakat, PSDKU Universitas Airlangga, Banyuwangi, Jawa Timur

${ }^{3}$ Departemen Epidemiologi, Fakultas Kesehatan Masyarakat, PSDKU Universitas Airlangga, Banyuwangi, Jawa Timur

${ }^{4}$ Departemen Gizi Kesehatan, Fakultas Kesehatan Masyarakat, PSDKU Universitas Airlangga, Banyuwangi, Jawa Timur

${ }^{5}$ Departemen Promosi Kesehatan dan Ilmu Perilaku, Fakultas Kesehatan Masyarakat, PSDKU Universitas Airlangga, Banyuwangi, Jawa Timur

${ }^{6}$ Research Group for Health \& Well-being of Women and Children, Fakultas Kesehatan Masyarakat, Universitas Airlangga

\section{PENDAHULUAN}

Remaja menurut WHO adalah fase kehidupan antara anak-anak dan dewasa, usia 10 hingga 19 tahun (WHO, 2020). Sedangkan menurut Peraturan Menteri Kesehatan RI nomor 25 tahun 2014, remaja adalah penduduk dalam rentang usia 10-18 tahun (Peraturan Menteri Kesehatan RI Nomor 75 Tahun 2014 Tentang Puskesmas, 2014). Remaja yang saat ini berumur 10 hingga 19 tahun termasuk dalam kategori generasi $\mathrm{Z}$. Generasi setelah generasi milenial disebut Generasi Z yang lahir rentang tahun 2001 sampai dengan 2010. Generasi Z merupakan peralihan dari Generasi Y atau generasi milenial pada saat teknologi sedang berkembang pesat. (Kementerian Pemberdayaan Perempuan dan Perlindungan Anak, 2018). Jumlah penduduk remaja di Indonesia tahun 2019 sebanyak 16.91\% (Badan Pusat Statistik Indonesia, 2020). Masa remaja merupakan masa kritis manusia dengan perkembangan fisik yang cepat, psikososial, perkembangan kognitif dan emosional, dan pematangan seksual dan reproduksi. Faktor biologi berdampak pada kesehatan remaja dan pembangunan; konteks sosial termasuk keluarga, media, sekolah, dan lingkungan tempat tinggal remaja hidup, belajar, dan tumbuh juga memiliki dampak besar pada kesehatan dan kesejahteraan mereka (Patton et al., 2016; Sawyer et al., 2012). Masa ini juga merupakan peluang kesehatan yang besar dan pondasi pola kesehatan orang dewasa di masa depan. Kesehatan pada masa remaja adalah hasil interaksi antara perkembangan prenatal dan anak usia dini serta perubahan peran biologis dan sosial spesifik yang menyertai pubertas; dibentuk oleh faktor determinan sosial dan risiko serta faktor protektif yang mempengaruhi adopsi perilaku terkait kesehatan. Fokus pada remaja merupakan pusat keberhasilan banyak program kesehatan masyarakat (Sawyer et al., 2012).

Masalah yang dihadapi remaja dapat berupa masalah kesehatan dan masalah lain yang berdampak terhadap kesehatan. Masalah kesehatan remaja yang dialami berdasarkan hasil Survei Demografi dan Kesehatan Indonesia (SDKI) tahun 2017 diantaranya merokok, minum-minuman beralkohol, dan penggunaan obat terlarang atau NAPZA (Narkotika, Psikotropika, dan Zat Adiktif lainnya). Persentase remaja pria yang merokok meningkat dari 53\% (SDKI 2012) menjadi 55\% (SDKI 2020). Sedangkan persentase remaja putri yang merokok pada tahun 2017 sebesar 1\%. Minum-minuman beralkohol pada remaja pria sebanyak $19 \%$ dan remaja putri sebesar 1\%. Penggunaan obat-obatan terlarang pada remaja pria sebesar 5\%. Hasil SDKI tahun 2017 juga menunjukkan perilaku berisiko terhadap kesehatan yaitu pengalaman melakukan hubungan seksual pada remaja pria sebesar $8 \%$ dan remaja wanita sebesar 2\%. Umur pertama kali berhubungan seksual tertinggi yaitu 17 tahun baik remaja pria maupun wanita (19\%). Kehamilan yang tidak diingikankan berdasarkan hasil SDKI 2017 terjadi pada $12 \%$ remaja wanita dan $7 \%$ remaja pria melaporkan pasangannya mengalami kehamilan yang tidak diinginkan (Badan Kependudukan dan Keluarga Berencana Nasional et al., 2018). Sedangkan masalah lain yang berdampak terhadap kesehatan salah satunya adalah pernikahan dini. Jumlah pernikahan dini di Kabupaten Banyuwangi pada tahun 2019 berdasarkan laporan perkara dispensasi kawin yang diputuskan Pengadilan Tinggi Agama Surabaya yaitu 352 perkara. Kabupaten Banyuwangi merupakan kabupaten dengan jumlah kasus pernikahan dini tertinggi di Jawa Timur tahun 2019 (Pengadilan Tinggi Agama Surabaya, 2020). Berdasarkan data di atas, dapat diketahui bahwa pernikahan dini merupakan masalah remaja di Kabupaten Banyuwangi. 
Pernikahan dini akan berdampak terhadap kesehatan remaja. Pernikahan dini memberikan dampak yang serius terhadap kesehatan reproduksi dan mental perempuan (Sezgin \& Punamäki, 2020)(Marphatia et al., 2017). Kehamilan di usia remaja akan meningkatkan risiko perinatal seperti berat badan lahir rendah (BBLR) atau prematur. Hasil studi di 23 negara yang berpenghasilan rendah dan menengah menunjukkan risiko yang lebih tinggi untuk BBLR, persalinan prematur, dan kondisi neonatal yang parah diantara ibu yang berusia 10-19 tahun dibandingkan ibu yang berusia lebih tua. Kehamilan di usia remaja juga dapat meningkatkan risiko kesehatan ibu hamil. Studi register di Amerika Serikat menunjukkan pada kehamilan dibawah 25 tahun ditemukan anemia dan risiko medis (seperti perdarahan, transfusi darah) secara signifikan lebih tinggi pada ibu yang berusia dibawah 16 tahun (Sezgin \& Punamäki, 2020). Kehamilan pada remaja juga berdampak terhadap kesehatan mental. Sebagian besar ibu hamil mengalami depresi tinggi terutama pada kehamilan dan pasca persalinan atau postpartum yang mencapai $40-50 \%$ termasuk gejala sedang sampai berat. Masalah kesehatan mental tersebut sampai ditemukan bukti bunuh diri dan menyakiti diri sendiri. Penelitian menunjukkan bahwa wanita dengan pernikahan dini dan kehamilan diusia remaja sangat rentan terhadap kekerasan dalam rumah tangga (KDRT) dan pasangan. KDRT dan kekerasan oleh pasangan ini meningkatkan masalah kesehatan mental seperti depresi dan bunuh diri. Wanita yang menikah muda memiliki akses yang lebih rendah terhadap kontrasepsi, ante-natal care (ANC), dan persalinan oleh tenaga kesehatan yang terampil atau di fasilitas pelayanan kesehatan. Ibu muda juga sangat rentan terhadap morbiditas dan mortalitas yang berkaitan dengan kehamilan misalnya eklampsia. Hal ini dipengaruhi oleh faktor fisiologis, bio-demografis, dan sosial (Marphatia et al., 2017). Komplikasi dari kehamilan dan persalinan merupakan penyebab utama kematian anak perempuan berusia 15 sampai 19 tahun di negara-negara berkembang (Maya et al., 2019) (Kartikawati, 2015). Pernikahan dini juga membatasi perkembangan kedewasaan fisik, emosional, dan pribadi yang diperlukan untuk keberhasilan dan keamanan transisi menuju dewasa(Sezgin \& Punamäki, 2020). Dengan demikian, pernikahan dini memiliki dampak yang besar bagi kesehatan masyarakat.

Penduduk usia remaja akan menjadi kelompok usia produktif di tahun 2020-2035. Mereka inilah yang akan menjadi penentu keberhasilan pembangunan di masa yang akan datang termasuk menentukan apakah Indonesia dapat menikmati bonus demografi dengan syarat utamanya tentulah mereka harus menjadi sumber daya yang sehat dan berkualitas. Masa remaja adalah masa penting untuk pertumbuhan kepemimpinan. Peningkatan kepemimpinan di masa remaja akan memperkuat harga diri dan menjadi katalisator untuk berkembang menjadi dewasa (Karagianni \& Jude Montgomery, 2018). Remaja dihadapkan pada tuntutan yang lebih sering dan kompleks pada pengambilan keputusan independen (Hartley \& Somerville, 2015). Remaja seharusnya memiliki kemampuan untuk membuat pilihan, bagaimana berperilaku hidup yang sehat dan menjadi pribadi yang bermanfaat. Oleh karena itu, penting untuk membekali remaja dengan pengetahuan dan kemampuan untuk menangkal pengaruh negatif yang sangat gencar, informasi kesehatan yang tidak benar (hoax) dan mencegah terjadinya perilaku yang berisiko terhadap kesehatan. Salah satu kemampuan yang perlu ditanamkan dan dibangun untuk remaja generasi $\mathrm{Z}$ adalah kepemimpinan (leadership) dan pengambilan keputusan (decision making) dalam bidang kesehatan remaja. Sehingga perlu dilaksanakannya pengabdian kepada masyarakat capacity building tentang leadership dan decision making bidang kesehatan remaja pada generasi Z di Kabupaten Banyuwangi Provinsi Jawa Timur. Tujuan dilaksanakannya kegiatan pengabdian kepada masyarakat ini yaitu meningkatkan pengetahuan tentang leadership dan decision making dalam kesehatan remaja pada generasi Z di Kabupaten Banyuwangi.

\section{METODE}

Metode kegiatan pengabdian kepada masyarakat Siap Jadi Pemimpin adalah edukasi secara daring. Edukasi dilaksanakan sebanyak 3 sesi. Setiap sesi diikuti oleh sasaran yang berbeda dengan Sasaran kegiatan ini adalah siswa kelas VII-XI di Kecamatan Licin dan Kecamatan Banyuwangi Kabupaten Banyuwangi. Kecamatan Licin mewakili daerah pedesaan, sedangkan Kecamatan Banyuwangi mewakili daerah perkotaan. Jumlah sasaran kegiatan adalah 441 orang yang terdiri dari siswa dan guru. Kegiatan ini dilaksanakan pada bulan Oktober 2020. Media edukasi yang digunakan adalah video, poster, dan slide presentasi. Evaluasi pengabdian kepada masyarakat meliputi kehadiran peserta, pelaksanaan kegiatan, dan pengetahuan peserta.

Evaluasi pelaksanaan kegiatan dilihat dari 5 aspek yaitu: acara dimulai tepat waktu, durasi waktu sesuai untuk menyampaikan materi, acara diakhiri tepat waktu, mendapatkan informasi baru, paham dengan informasi yang diberikan. Rentang skor yaitu 1-5 (Sangat Tidak Baik, Tidak Baik, Cukup, Baik, Sangat Baik). Jumlah peserta yang mengisi form evaluasi sebanyak 78 orang. Nilai terendah didapatkan dari perhitungan jumlah peserta x skor terendah x jumlah pertanyaan yaitu 78 x 1 x 5. Jumlah nilai terendah adalah 390 . Sedangkan nilai tertinggi didapatkan dari perhitungan jumlah peserta $\mathrm{x}$ skor tertinggi $\mathrm{x}$ jumlah pertanyaan yaitu 78 x 5 x 5. Jumlah nilai tertinggi adalah 1950. Kategori evaluasi kegiatan sebanyak 5 kategori, sehingga rentang nilai kategori didapatkan dari perhitungan jumlah nilai tertinggi - jumlah nilai terendah kemudian dibagi 5 yaitu 312. Berikut ini adalah nilai dan kategori evaluasi kegiatan. 
Tabel 1. Nilai dan Kategori Evaluasi Kegiatan

\begin{tabular}{ll}
\hline Nilai & Kategori \\
\hline $390-702$ & Sangat Tidak Baik \\
$703-1014$ & Tidak Baik \\
$1015-1326$ & Cukup \\
$1327-1638$ & Baik \\
$1639-1950$ & Sangat Baik \\
\hline
\end{tabular}

Evaluasi pengetahuan berdasarkan 10 pertanyaan dari materi yang telah disampaikan di video edukasi. Aspek yang dinilai adalah pengertian, tujuan, cara menumbuhkan, dan karakteristik dari leadership serta pengertian dan cara melatih decision making skill. Jawaban benar nilai 1 dan jawaban salah nilai 0. Persentase nilai pretest/posttest didapatkan dari nilai total jawaban benar dari masing-masing pertanyaan dibagi nilai maksimal jawaban benar dikali $100 \%$.

\section{HASIL DAN PEMBAHASAN}

Pelaksanaan kegiatan pengabdian kepada masyarakat Siap Jadi Pemimpin terdiri dari dua tahap yaitu persiapan media edukasi dan pelaksanaan edukasi. Media edukasi yang disiapkan adalah video dan poster. Gambar 1 dibawah ini menunjukkan desain cover video edukasi. Video edukasi Siap Jadi Pemimpin berdurasi 6 menit 29 detik. Sedangkan desain poster dapat dilihat pada gambar 2 di bawah ini.

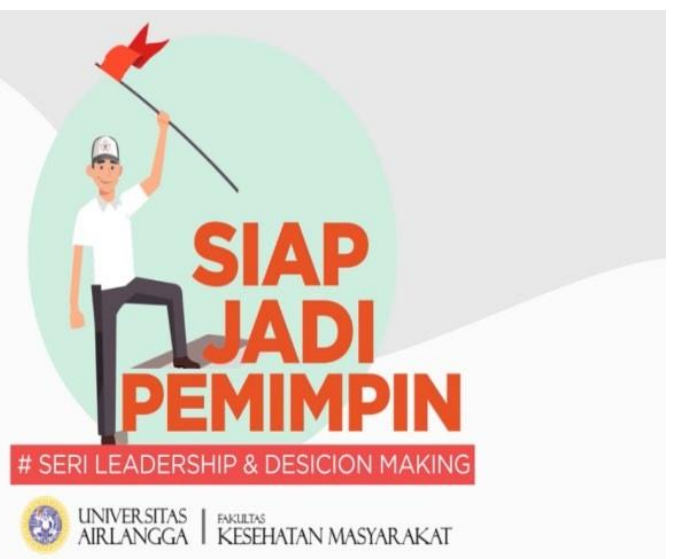

Gambar 1. Desain Cover Video Edukasi

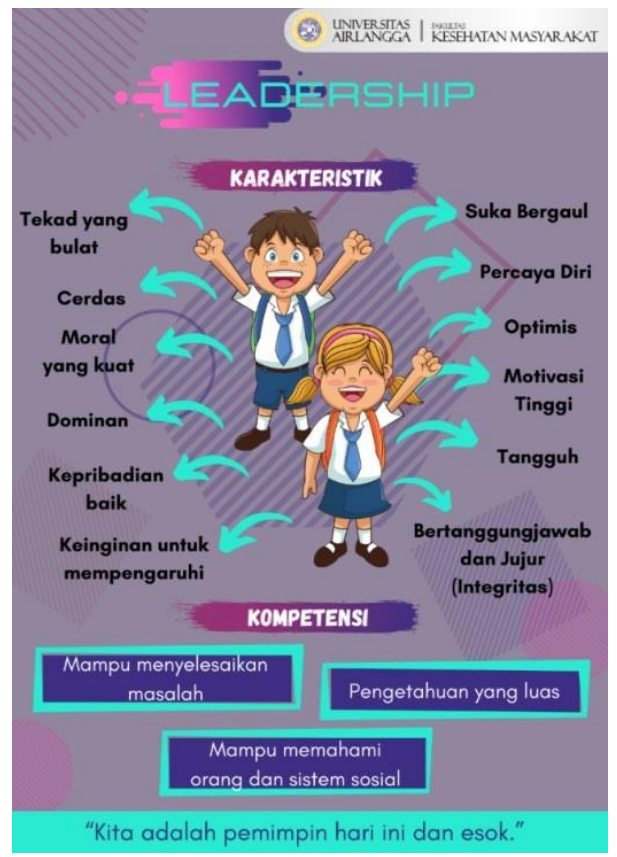

Gambar 2. Desain Poster Edukasi 
Kegiatan edukasi tentang leadership dan decision making dalam kesehatan remaja dilaksanakan secara daring. Sekolah yang menjadi peserta edukasi daring yaitu SMPN 4 Banyuwangi, SMP PGRI 2 Banyuwangi, SMPN 2 Glagah, SMA Muhammadiyah 1 Banyuwangi, dan SMAN 1 Banyuwangi. Kelima sekolah ini terletak di Kecamatan Banyuwangi. Sedangkan SMPN2 Licin Satu Atap, MTs Nahdatul Wathon, dan MA Nahdatul Wathon terletak di Kecamatan Licin. Sasaran ketiga sekolah di Kecamatan Licin tersebut tidak bisa mengikuti kegiatan sosialisasi secara daring karena terkendala jaringan. Sehingga edukasi diberikan melalui pembagian media cetak (poster), media elektronik (video dan file presentasi) kepada sekolah tersebut.

Kegiatan edukasi dilaksanakan pada tanggal 22 dan 23 Oktober 2020 dalam tiga sesi zoom meeting. Pembagian sesi tersebut dibedakan berdasarkan tingkatan sekolah yaitu SMP dan SMA serta jumlah siswa. Pelaksanaan kegiatan edukasi daring melalui zoom meeting. Kegiatan ini diikuti oleh 120 peserta. Persentase kehadiran peserta:undangan adalah 120:441 atau 27,21\%. Acara dibuka oleh Dekan Fakultas Kesehatan Masyarakat Universitas Airlangga dan Kaprodi PSDKU Universitas Airlangga di Banyuwangi. Secara umum, kegiatan terlaksana sesuai jadwal acara. Gambaran pelaksanaan pengabdian kepada masyarakat ditampilkan pada gambar 3. Secara umum, tidak ada hambatan dalam pelaksanaan kegiatan di sesi 1, 2, dan 3.

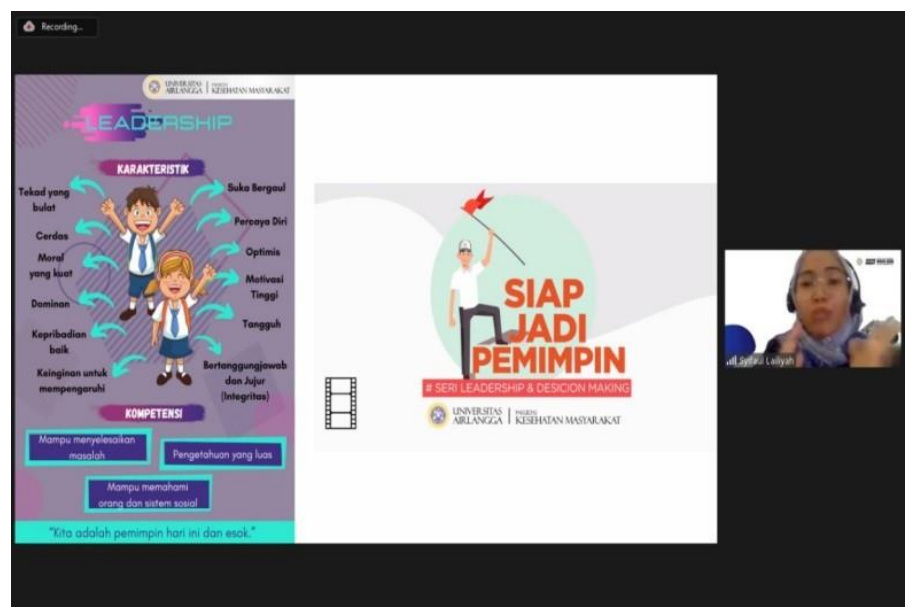

Gambar 3. Narasumber Menyampaikan Materi dalam Pelaksanaan Pengabdian kepada Masyarakat Siap Jadi Pemimpin

Perhitungan nilai total evaluasi kegiatan oleh peserta yaitu 1676. Berdasarkan nilai total kegiatan pada tabel 2 dan kategori evaluasi kegiatan pada tabel 1, maka dapat disimpulkan bahwa pelaksanaan kegiatan pengabdian kepada masyarakat termasuk dalam kategori sangat baik. Perubahan tingkat pengetahuan tentang leadership dan decision making diketahui dari hasil penilaian pretest dan posttest. Hasil pretest dan posttest dapat dilihat pada gambar 4 di bawah ini.

Tabel 2. Hasil Evaluasi Kegiatan

\begin{tabular}{|c|c|c|c|c|c|c|c|c|c|c|c|c|}
\hline \multirow{3}{*}{ Aspek Penilaian } & \multicolumn{10}{|c|}{ Skor } & \multirow{2}{*}{\multicolumn{2}{|c|}{ Jumlah }} \\
\hline & \multicolumn{2}{|r|}{1} & \multicolumn{2}{|r|}{2} & \multicolumn{2}{|r|}{3} & \multicolumn{2}{|r|}{4} & \multicolumn{2}{|r|}{5} & & \\
\hline & $\mathrm{n}$ & $\%$ & $\mathrm{n}$ & $\%$ & $\mathrm{n}$ & $\%$ & $\mathrm{n}$ & $\%$ & $\mathrm{n}$ & $\%$ & $\mathrm{~N}$ & $\%$ \\
\hline $\begin{array}{l}\text { Acara dimulai tepat } \\
\text { waktu }\end{array}$ & 3 & 3,85 & 3 & 3,85 & 9 & 11,54 & 16 & 20,51 & 47 & 60,26 & 78 & 100 \\
\hline $\begin{array}{l}\text { Durasi waktu sesuai } \\
\text { untuk menyampaikan } \\
\text { materi }\end{array}$ & 1 & 1,28 & 4 & 5,13 & 11 & 14,10 & 22 & 28,21 & 40 & 51,28 & 78 & 100 \\
\hline $\begin{array}{l}\text { Acara diakhiri tepat } \\
\text { waktu }\end{array}$ & 1 & 1,28 & 8 & 10,26 & 15 & 19,23 & 14 & 17,95 & 40 & 51,28 & 78 & 100 \\
\hline $\begin{array}{l}\text { Peserta mendapatkan } \\
\text { informasi baru }\end{array}$ & 1 & 1,28 & 1 & 1,28 & 7 & 8,97 & 22 & 28,21 & 47 & 60,26 & 78 & 100 \\
\hline $\begin{array}{l}\text { Peserta paham dengan } \\
\text { informasi } \\
\text { diberikan }\end{array}$ & 0 & 0 & 1 & 1,28 & 10 & 12,82 & 21 & 26,92 & 46 & 58,97 & 78 & 100 \\
\hline Jumlah Skor & 6 & 0,36 & 34 & 2.03 & 156 & 9.31 & 380 & 22.67 & 1100 & 65.63 & 1676 & 100 \\
\hline
\end{tabular}




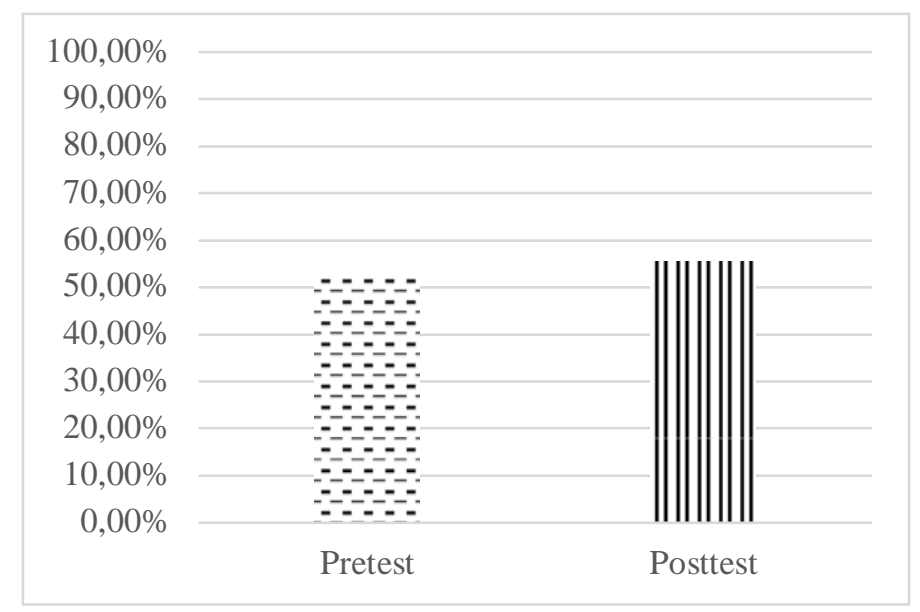

Gambar 4. Hasil Pretest dan Posttest Pengetahuan tentang Leadership dan Decision Making

Jumlah peserta yang mengisi pretest dan posttest sebanyak 44 orang. Hasil pretest dan posttest menunjukkan bahwa peningkatan pengetahuan siswa tentang leadership dan decision making sebesar $3.63 \%$. Jika dilihat dari jumlah peserta yang pengetahuannya meningkat yaitu sebanyak 16 orang (36.36\%). Sedangkan jika dilihat dari skor peningkatan nilai dari 16 orang tersebut, peningkatan pengetahuan sebesar $15.63 \%$.

Pengabdian kepada masyarakat merupakan salah satu tridharma perguruan tinggi berupa kegiatan sivitas akademika yang memanfaatkan ilmu pengetahuan dan teknologi untuk memajukan kesejahteraan masyarakat dan mencerdaskan kehidupan bangsa (Undang-Undang Republik Indonesia Nomor 12 Tahun 2012 Tentang Pendidikan Tinggi, 2012). Pengabdian kepada masyarakat Siap Jadi Pemimpin memberikan edukasi tentang kepemimpinan atau leadership dan pengambilan keputusan atau decision making kepada remaja yang sedang menempuh Pendidikan tingkat menengah. Pelaksanaan edukasi ini dilakukan secara daring dengan pertimbangan situasi pandemi COVID-19 menggunakan media pembelajaran audio visual. Peningkatan pengetahun peserta edukasi secara daring ini tidak belum terlalu signifikan yaitu sebesar 3,63\%. Hasil penelitian di Surabaya tentang ekstrakurikuler Paskibra yaitu ada hubungan yang kuat antara kegiatan Paskibra dengan kepemimpinan siswa dengan nilai korelasi 0,63. Ekstrakurikuler Paskibra melatih dan mengembangkan sifat integritas, tegas dalam pengambilan keputusan, cerdas dan memiliki kepercayaan. Keempat sifat ini merupakan karakteristik dari leadership. Pemimpin tidak hanya mampu mengkoordinir dan mengarahkan anggotanya tetapi juga memberi contoh yang baik bagi anggotanya (Ratnasari, 2013). Siswa yang mengikuti ekstrakurikuler Paskibra menjadi percaya diri dan merasa bisa mempimpin diri sendiri dan temannya (Putra, 2018). Hasil penelitian di Bandung tahun 2016 menunjukkan bahwa ada kecenderungan siswa yang mengikuti ekstrakurikuler pecinta alam memiliki potensi kepemimpinan. Siswa tersebut telah mendapatkan serangkaian pendidikan dan latihan tentang pemantapan, pengembaraan dan karya tulis (Raharja, 2016). Selain itu, bagi siswa yang aktif di organisasi kesiswaan seperti OSIS sudah mendapatkan informasi tentang leadership dalam kegiatan Latihan Dasar Kepemimpinan Siswa (LDKS). LDKS memberikan dukungan positif dan signifikan terhadap peningkatan kepemimpinan siswa PRAMUKA sebagaimana hasil penelitian di Serang (Sabda, 2019).

Siswa yang terpapar informasi tentang kepemimpinan harapannya tidak hanya yang aktif di ekstrakurikuler dan organisasi kesiswaan, tetapi juga siswa yang pasif dalam kegiatan kesiswaan di sekolah. Hasil pretest dan posttest kegiatan pengabdian kepada masyarakat ini menunjukkan bahwa nilai pengetahuan siswa tentang leadership dan decision making dibawah 60\%. Hal ini berarti dalam rangka meningkatkan pengetahuan leadership dan decision making tidak bisa dilakukan dalam satu kali kegiatan. Harus dilakukan secara periodik dan berkesinambungan. Sejalan dengan hasil evaluasi Program Edukator Sebaya Pendidikan Kesehatan Berbasis Sekolah untuk remaja perempuan di India bahwa ada peningkatan keterampilan leadership yang signifikan pada edukator sebaya selama kurun waktu satu tahun (Shankar et al., 2020).

Aspek penting perkembangan remaja yang berkaitan dengan perilaku kesehatan meliputi otonomi, proses kognitif, dan pengaruh sosial. Otonomi memberi remaja kesempatan untuk terlibat dalam decision making kesehatan yang bergantung dengan konsekuensi seumur hidup. Keterampilan decision making pada remaja belum berkembang sepenuhnya. Albert dan Steinberg (2011) dalam (Fleary et al., 2018) mengemukakan bahwa decision making pada remaja dipengaruhi oleh faktor sosio-emosional dan pengaturan diri. Demikian pula, Blakemoreand Robbins (2012) dalam (Fleary et al., 2018) mengemukakan bahwa perkembangan yang lambat dari kontrol impuls dan penghambatan respon meningkatkan ketergantungan remaja pada faktor sosial dan emosi untuk membuat keputusan. Sehingga, remaja lebih cenderung membuat keputusan yang tidak disengaja. Mengingat hal ini dan konsekuensi jangka panjang dari perilaku kesehatan remaja, intervensi perilaku kesehatan harus difokuskan pada decision making remaja. Decision making berdasarkan (Prajapati et al., 2017) merupakan salah satu kemampuan inti dalam life skills education. Keterampilan ini sebagai supportive system 
untuk remaja yang dapat mengubah sikap, pandangan, dan perilaku remaja yang lebih positif. Pelatihan life skills di wilayah Cipayung Jakarta Timur Indonesia menunjukkan bahwa terdapat perbedaan signifikan pada pengetahuan, sikap, dan keterampilan antara kelompok intervensi yang mendapat perlakuan berupa pemberian modul dan buku pemantauan disertai pelatihan dengan kelompok kontrol yang hanya diberikan modul dan buku tanpa disertai pelatihan life skills. Pelatihan life skills remaja dapat digunakan sebagai salah satu intervensi dalam upaya mencegah HIV/AIDS pada remaja. Jika remaja memiliki life skills yang baik, maka mereka akan terhindar dari penyimpangan perilaku seksual pranikah yang berisiko terhadap HIV/AIDS (Ekasari et al., 2020). Peningkatan pengetahuan tentang leadership dan decision making pada kegiatan pengabdian kepada masyarakat ini merupakan tahap awal dalam rangka menumbuhkan kemampuan atau skills leadership dan decion making remaja.

Remaja banyak dipengaruhi oleh orang tua dan teman sebaya, bahkan berbagai pendorong baru bermunculan. Pemasaran produk dan gaya hidup yang tidak sehat (contohnya: rokok, alkohol, dan makanan tinggi lemak, gula, dan garam) jelas menargetkan kaum muda (Sawyer et al., 2012). Pengetahuan dan kemampuan leadership dan decision making yang telah didapatkan harapannya tidak hanya diterapkan dalam kegiatan-kegiatan kesiswaan tetapi juga diterapkan dalam bidang kesehatan remaja. Sehingga remaja mampu mengambil keputusan bagi kesehatannya misalnya mampu mempertimbangkan risiko kesehatan, memilih untuk tidak merokok dan minum-minuman beralkohol, memilih makanan yang sehat dan bergizi, tidak melakukan seks pranikah, dan tidak melakukan pernikahan dini. Remaja juga bisa mengajak teman-temannya untuk melaksanakan pola hidup bersih dan sehat. Remaja yang sehat merupakan investasi sumber daya kesehatan yang berkualitas di masa yang akan datang.

\section{KESIMPULAN}

Kegiatan pengabdian kepada masyarakat ini dapat meningkatkan pengetahuan peserta kegiatan tentang leadership dan decision making dalam kesehatan remaja pada generasi Z di Kabupaten Banyuwangi.

\section{ACKNOWLEDGEMENT}

Ucapan terima kasih kepada Fakultas Kesehatan Masyarakat Universitas Airlangga, anggota tim pengabdian kepada masyarakat Fakultas Kesehatan Masyarakat Universitas Airlangga, dan mitra pengabdian kepada masyarakat.

\section{REFERENSI}

Badan Kependudukan dan Keluarga Berencana Nasional, Badan Pusat Statistik, \& Kementerian Kesehatan. (2018). Survei Demografi Dan Kesehatan Indonesia 2017: Kesehatan Reproduksi Remaja. In Badan Kependudukan dan Keluarga Berencana Nasional Badan Pusat Statistik Kementerian Kesehatan. https://e-koren.bkkbn.go.id/wp-content/uploads/2018/10/Laporan-SDKI-2017-Remaja.pdf

Badan Pusat Statistik Indonesia. (2020). Statistik Indonesia 2020.

https://www.bps.go.id/publication/2020/02/28/6e654dd717552e82fb3c2ffe/statistik-indonesia-penyediaan-data-untuk-perencanaan-pembangunan.html

Ekasari, M. F., Rosidawati, R., \& Jubaedi, A. (2020). Peningkatan Kemampuan Remaja Menghindari HIV/AIDS Melalui Pelatihan Keterampilan Hidup. Jurnal Ilmu Kesehatan Masyarakat, 9(03), 164171. https://doi.org/10.33221/jikm.v9i03.520

Fleary, S. A., Joseph, P., \& Pappagianopoulos, J. E. (2018). Adolescent health literacy and health behaviors: A systematic review. Journal of Adolescence, 62(March 2017), 116-127. https://doi.org/10.1016/j.adolescence.2017.11.010

Hartley, C. A., \& Somerville, L. H. (2015). The neuroscience of adolescent decision-making. Current Opinion in Behavioral Sciences, 5, 108-115. https://doi.org/10.1016/j.cobeha.2015.09.004

Karagianni, D., \& Jude Montgomery, A. (2018). Developing leadership skills among adolescents and young adults: a review of leadership programmes. International Journal of Adolescence and Youth, 23(1), 86-98. https://doi.org/10.1080/02673843.2017.1292928

Kartikawati, R. (2015). Dampak Perkawinan Anak di Indonesia. Jurnal Studi Pemuda, 3(1), 1-16. https://journal.ugm.ac.id/jurnalpemuda/article/view/32033/19357

Peraturan Menteri Kesehatan RI Nomor 75 Tahun 2014 Tentang Puskesmas, Kementerian Kesehatan (2014).

Kementerian Pemberdayaan Perempuan dan Perlindungan Anak. (2018). Profil Generasi Milenial Indonesia. https://www.kemenpppa.go.id/lib/uploads/list/9acde-buku-profil-generasi-milenia.pdf

Marphatia, A. A., Ambale, G. S., \& Reid, A. M. (2017). Women's Marriage Age Matters for Public Health: A Review of the Broader Health and Social Implications in South Asia. Frontiers in Public Health, 5. https://doi.org/10.3389/fpubh.2017.00269 
Maya, R. . A., Andriani, R., \& Priyanti, E. (2019). Pendidikan Kesehatan tentang Dampak Pernikahan Dini Terhdap Kehamilan Remaja di SMA Negeri 14 Palembang. Khidmah Jurnal Pengabmas IkesT Muhammadiyah Palembang, 2(1), 90-95. http://khidmah.ikestmp.ac.id/index.php/khidmah/article/view/295/252

Patton, G. C., Sawyer, S. M., Santelli, J. S., Ross, D. A., Afifi, R., Allen, N. B., Arora, M., Azzopardi, P., Baldwin, W., Bonell, C., Kakuma, R., Kennedy, E., Mahon, J., McGovern, T., Mokdad, A. H., Patel, V., Petroni, S., Reavley, N., Taiwo, K., .. Viner, R. M. (2016). Our future: a Lancet commission on adolescent health and wellbeing. The Lancet, 387(10036), 2423-2478. https://doi.org/10.1016/S01406736(16)00579-1

Undang-Undang Republik Indonesia Nomor 12 Tahun 2012 Tentang Pendidikan Tinggi, (2012). https://lldikti8.ristekdikti.go.id/2019/02/05/undang-undang-republik-indonesia-nomor-12-tahun-2012tentang-pendidikantinggi/\%0Ahttps://www.ilo.org/dyn/natlex/natlex4.detail?p_lang=en\&p_isn=84435

Pengadilan Tinggi Agama Surabaya. (2020). Laporan Perkara yang Diputus Pengadilan Tinggi Agama Surabaya Bulan Januari-Desember 2019. https://pta-surabaya.go.id/pages/laporan-perkara\#tk32020

Prajapati, R., Sharma, B., \& Sharma, D. (2017). Kĩ Năng ( Tiếng Anh).Pdf. 10(1), 1-6. https://files.eric.ed.gov/fulltext/EJ1126842.pdf

Putra, N. L. J. (2018). Upaya Pembentukan Jiwa Kepemimpinan Peserta Didik Melalui Kegiatan Paskibra. Jurnal Ilmu Pendidikan STKIP Kusuma Negara, 10(1), $32-50$. http://jurnal.stkipkusumanegara.ac.id/index.php/jip/article/view/4/4

Raharja, R. M. (2016). Upaya Pembinaan Karakter Dan Potensi Kepemimpinan Siswa Melalui Kegiatan Ekstrakulikuer Pencinta Alam Di Sman 2 Bandung. Untirta Civic Education Journal, 1(1), 85-95. https://doi.org/10.30870/ucej.v1i1.1878

Ratnasari, N. D. dan S. (2013). Hubungan kegiatan ekstrakurikuler Pasukan Pengibar Bendera (PASKIBRA) dengan kepemimpinan peserta didik SMA Kartika IV-3 Surabaya. Jurnal Kajian Moral Dan Kewarganegaraan, 2(1), 380-395. https://jurnalmahasiswa.unesa.ac.id/index.php/jurnal- pendidikankewarganegaraa/article/view/3753

Sabda, M. (2019). Hubungan Latihan Dasar Kepemimpinan Siswa (LDKS) Dan Kecerdasan Emosional Terhadap Kepemimpinan Siswa Pramuka [Universitas Islam Negeri Serang Banten]. In Universitas Islam Negeri Serang Banten. http://repository.uinbanten.ac.id/3900/

Sawyer, S. M., Afifi, R. A., Bearinger, L. H., Blakemore, S. J., Dick, B., Ezeh, A. C., \& Patton, G. C. (2012). Adolescence: A foundation for future health. The Lancet, 379(9826), 1630-1640. https://doi.org/10.1016/S0140-6736(12)60072-5

Sezgin, A. U., \& Punamäki, R. L. (2020). Correction to: Impacts of early marriage and adolescent pregnancy on mental and somatic health: the role of partner violence (Archives of Women's Mental Health, (2020), 23, 2, (155-166), 10.1007/s00737-019-00960-w). Archives of Women's Mental Health, 23(2), 155-166. https://doi.org/10.1007/s00737-019-00971-7

Shankar, P., Sievers, D., \& Sharma, R. (2020). Evaluating the Impact of A School-based Youth-led Halth Education Program for Adolescent Females in Mumbai, India. Annals of Global Health, 86(1), 1-9. https://doi.org/10.5334/aogh.2791

WHO. (2020). Adolescent Health. https://www.who.int/health-topics/adolescent-health\#tab=tab_1 